\title{
Weights and Measures of Eighteenth-Century Language : A Sociolinguistic Account of Montagu's Correspondence
}

\section{Sairio, Anni}

2018

Sairio , A 2018 , ' Weights and Measures of Eighteenth-Century Language : A Sociolinguistic Account of Montagu's Correspondence ', Huntington Library Quarterly , vol. 81 , no. 4 , pp. 633-656 . https://doi.org/10.1353/hlq.2018.0024

http://hdl.handle.net/10138/325463

https://doi.org/10.1353/hlq.2018.0024

publishedVersion

Downloaded from Helda, University of Helsinki institutional repository.

This is an electronic reprint of the original article.

This reprint may differ from the original in pagination and typographic detail.

Please cite the original version. 


\title{
Weights and Measures of Eighteenth- Century Language: A Sociolinguistic Account of Montagu's Correspondence
}

\author{
Anni Sairio
}

\begin{abstract}
A BS TR ACT In this essay, Anni Sairio explores sociolinguistic variation and change in Elizabeth Montagu's personal letters from the 1730 s to the 178 os. Corpus analysis of the letters focuses on language features with normative and (in)formal connotations. The language of Montagu's letters changed considerably in the 1750 s and 1760 s, which indicates that her position in the Bluestocking network and her new social role had linguistic influence. On the one hand, preposition stranding all but disappeared as her social status became more prominent. On the other hand, Montagu's spelling became increasingly informal over the years, which suggests a kind of indifference to the ongoing language standardization. Contracted and abbreviated spellings were also more frequent in her letters to women. Life events, social relationships, and macrolevel linguistic developments all play a part in the variation and change of Montagu's language. In "'The Commerce of Life': Elizabeth Montagu (1718-180o)," ed. Nicole Pohl, special issue, http://doi.org/10.1353/hlq.2018.0030 KE Y WOR D S: eighteenth-century sociolinguistics; spelling variation; preposition stranding; eighteenth-century grammars; gender and spelling
\end{abstract}

Another Commentator, and Another.

To choak my Flame with all their Critic Smother!

Ye sacred Nine! from who I caught the Flame,

Will you permit these Goths to sink my Fame?

Clogg'd with their Load in vain she upward springs,

In vain my Muse would free her limed Wings;

O let not Diggers, Delvers, Derivators,

These Comma-Mongers, Porers, and Collators,

Their Clouds of Dulness o'er my Works disperse.

Maiming the Passion to eke out the Verse;

And like Lord May'rs, inspect my sacred Treasures,

HUNTINGTON LIBRARY QUARTERLY | VOL. 81, NO. 4

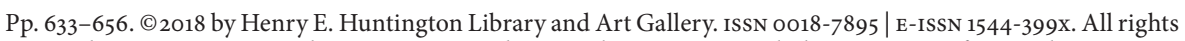
reserved. For permission to photocopy or reproduce article content, consult the University of Pennsylvania Press Rights and Permissions website, http://www.upenn.edu/pennpress/about/permissions.html. 
Fixing the Standard by their Weights and Measures:

Against my Foes your best Assistance send me,

Let Garrick Act, and Montagu defend me. ${ }^{1}$

IN THIS ANONYMOUS POEM-assumed to date to 1769, perhaps because Elizabeth Montagu's Essay on the Writings and Genius of Shakespear was published that year-Shakespeare frets over boorish and pedantic emendators and commentators who meddle with his work. ${ }^{2} \mathrm{He}$ asks the muses to send him assistance of the best kind: David Garrick to perform his plays and Montagu to speak for him. The poem illustrates Montagu's connection to a figure of national pride and, metaphorically, to the ideology of standardization in eighteenth-century England. 3 I would like to consider this verse from the perspective of the eighteenth-century normative traditionthe codification of the standard language-and how its "Weights and Measures" are reflected in Montagu's private language use. At the time, there were actually two standards: one for public and one for private writing, and this latter standard retained variant forms that were disappearing from printed works.

The codification of language in grammars and dictionaries is one of the final stages in the standardization process. Codifiers typically establish clear standards and norms for language users. Comma-mongers they may be, but their potential influence is significant. The transition from codification to prescription is impossible to identify precisely, but prescriptivism begins to play a major role in England in grammars written between 1745 and 1770. 4 Robert Lowth's Short Introduction to English Grammar (1762) promoted the language use of the "polite" and "learned" as a model and was an instant best seller, and Samuel Johnson's Dictionary of the English Language (1755) was received with great admiration. ${ }^{5}$ Linguistic uniformity was

1. "Upon Advertising a New Edition of Shakespeare, Shakespeare Loquitur," manuscript transcript poem, [1769?], MS Hyde 7 (22), Houghton Library, Harvard University.

2. The manuscript may have been copied from an anonymously published verse that appeared in the Poets' Corner of the St. James's Chronicle on February 5, 1771; see Antonia Forster, "Shakespeare in the Reviews," in Shakespeare in the Eighteenth Century, ed. Fiona Ritchie and Peter Sabor (Cambridge, 2012), 73.

3. For the ideology of the standard, see James and Lesley Milroy, Authority in Language: Investigating Standard English (London, 1999). See also Elizabeth Eger, "Out Rushed a Female to Protect the Bard": The Bluestocking Defense of Shakespeare," in "Reconsidering the Bluestockings," ed. Nicole Pohl and Betty A. Schellenberg, special issue, Huntington Library Quarterly 65, no. $1 / 2$ (2002): 127-51.

4. Ingrid Tieken-Boon van Ostade, "Grammars, Grammarians and Grammar Writing: An Introduction," Grammars, Grammarians and Grammar-Writing in Eighteenth-Century England, ed. Tieken-Boon van Ostade, Topics in English Linguistics 59 (Berlin, 2008), 8.

5. Ingrid Tieken-Boon van Ostade, "English at the Onset of the Normative Tradition," The Oxford History of English, ed. Lynda Mugglestone, rev. ed. (Oxford, 2012), 298-339; Grammars, Grammarians and Grammar-Writing, ed. Tieken-Boon van Ostade. See also James Milroy, "Language Ideologies and the Consequences of Standardization," Journal of Sociolinguistics 5, no. 4 (2001): 530-55. 
the ideal; the discussions of variation in seventeenth- and early eighteenth-century grammars increasingly accepted the notion that variant forms (such as walk' $d$ for walked) were irregularities to be weeded out of the language. ${ }^{6}$ The increase of grammars in the eighteenth century resulted from the following factors: first, there was no academy to establish linguistic rules, so the work was in the hands of individuals; and second, increased social mobility produced a readership that needed linguistic guidance in order to accelerate their social advancement. ${ }^{7}$ Access to high social status was linked with access to the legitimate language variety, and particularly in the first half of the eighteenth century, politeness was connected with language use as a marker of social status. $^{8}$

Language functioned as perhaps the most significant marker of politeness. The values of politeness-decorum, grace, beauty, symmetry, and order-were "transformed into the social symbols for membership in the class of the gentry that the upwardly mobile emergent middle classes eagerly sought to attain" and were thus associated with features of "standard English."9 Grammars were tools for the upwardly mobile_- "passports for politeness," as Carol Percy notes ${ }^{10}$ - and they were mainly directed at those who did not receive a classical education (women, dissenters, and the middle classes). Grammars implied that the appropriate models for correct language use were members of the polite world with a liberal educationin other words, men of high prestige. ${ }^{11}$ The codification process was in the hands of schoolteachers, clergymen, poets, and scientists, who were informed mostly by their own observations. Their analysis of sources was unsystematic, but toward the end of

6. Kari Haugland, "Is't allow'd or ain't it? On Contraction in Early Grammars and Spelling Books," Studia Neophilologica 67, no. 2 (1995): 165-84.

7. Tieken-Boon van Ostade, "Grammars, Grammarians and Grammar Writing: An Introduction," 4, 10.

8. Richard J. Watts, "Language and Politeness in Early Eighteenth Century England," Pragmatics 9, no. 1 (1999): 6.

9. Richard J. Watts, "A Socio-Cognitive Approach to Historical Politeness," in Understanding Historical (Im)Politeness: Relational Linguistic Practice over Time and across Cultures, ed. Marcel Bax and Dániel Z. Kádár (Amsterdam, 2012), 117.

10. Carol Percy, "Mid-Century Grammars and Their Reception in the Monthly Review and the Critical Review," in Grammars, Grammarians and Grammar-Writing, ed. Tieken-Boon van Ostade, 130.

11. Joan C. Beal, English in Modern Times, 1700-1945 (London, 2004); Grammars, Grammarians, and Grammar-Writing, ed. Tieken-Boon van Ostade; Ian Michael, "More Than Enough English Grammars," in English Traditional Grammars: An International Perspective, ed. Gerhard Leitner (Amsterdam, 1991), 11-26; Ian Michael, English Grammatical Categories and the Tradition to 1800 (London, 1970); Susan Fitzmaurice, "The Commerce of Language in the Pursuit of Politeness in Eighteenth-Century England," English Studies 79, no. 4 (1998): 309-28; Ingrid Tieken-Boon van Ostade, "The 1760s: Grammars, Grammarians and the Booksellers," in Grammars, Grammarians and Grammar-Writing, ed. Tieken-Boon van Ostade, $101-24$. 
the century, we begin to find grammarians whose approach to language is empirical and who can be considered language experts in the linguistic sense. ${ }^{12}$

In this essay, I explore sociolinguistic variation in Elizabeth Montagu's private correspondence, with a particular focus on language use that had normative connotations. I am interested in how Montagu reacts to advancing linguistic prescriptivism; how (or if) the sociolinguistic variables of gender, age, and rank of Montagu and her correspondents correlate with her language use; and how life events may be linked to her language change. Comprehensive research into an individual's language use throughout the life span, through quantitative macrolevel analysis and close readings of texts, introduces the concept of linguistic biography. The researcher takes up the role of a biographer and explores an individual's language through the social and cultural dimensions of his or her society. ${ }^{13}$ The purpose of a linguistic biography is to carry out a sociolinguistic analysis of an individual's language use (that is, idiolect) and to contextualize the findings with regard to key events in the individual's life as well as language variation and change at the societal level. Social network analysis provides a framework for understanding social relationships and reactions to linguistic innovations. To accomplish this requires a wealth of language data, biographical information, baseline data about general trends in the language, and familiarity with the social structure of the society at large and the relevant social circles more specifically.

Barbara Johnstone has developed the concept of lingual biography in her work on the language of the individual in a present-day framework, which largely centers on the concept of stance as an index of social and personal identity. ${ }^{14}$ In historical sociolinguistics, Helena Raumolin-Brunberg has explored the language change and variation of early modern English gentlemen Sir Thomas More, Sir Walter Ralegh, Philip Gawdy, and John Chamberlain throughout their life spans. ${ }^{15}$ She notes that, despite their similar social backgrounds, individuals appear to "make their own choices from the repertory of linguistic variants used among their social

12. Ingrid Tieken-Boon van Ostade, "Background: Introduction," in Grammars, Grammarians and Grammar-Writing in Eighteenth-Century England, ed. Tieken-Boon van Ostade, 18.

13. See Barbara Johnstone, "Lingual Biography and Linguistic Variation," Language Sciences 21 (1999): 313-21.

14. Johnstone, "Lingual Biography and Linguistic Variation"; Johnstone, "Linking Identity and Dialect through Stancetaking," in Stancetaking in Discourse: Subjectivity, Evaluation, Interaction, ed. Robert Englebretson (Amsterdam, 2007), 49-68; Johnstone, "Stance, Style, and the Linguistic Individual," in Sociolinguistic Perspectives on Stance, ed. Alexandra Jaffe (New York, 2009), 29-52.

15. Helena Raumolin-Brunberg, The Noun Phrase in Early Sixteenth-Century English: A Study Based on Sir Thomas More's Writings (Helsinki, 1991); Raumolin-Brunberg, "Lifespan Changes in the Language of Three Early Modern Gentlemen," in The Language of Daily Life in England (1400-1800), ed. Arja Nurmi, Minna Nevala, and Minna Palander-Collin (Amsterdam, 2009), 165-96. 
groups in order to create and support their identities and personal styles." Change occurs throughout a life span, and migration patterns and social mobility are likely to be involved. ${ }^{16}$ As John Edwards argues, "Idiolectal usage [can be viewed as] a social, or group, phenomenon, on the simple grounds that all (well, almost all) language implies someone to talk to, a communicative intent, a linking of the individual to others." 17 Social identity is indeed a key element in this type of research. As for sources of influence, Ingrid Tieken-Boon van Ostade suggests that the private idiolect of the bishop and grammarian Robert Low th did not match the norms of proper English that he advocated in his best-selling grammar, and she argues that Lowth based his grammatical strictures on the language of his social superiors, thus showing himself as a true social climber. ${ }^{18} \mathrm{Mel}$ Evans investigates change, variation, and stability in the idiolect of Elizabeth I within a cross-disciplinary framework of style and community of practice, taking into account Elizabeth's life events and the macrolevel developments in Early Modern English, showing that she was in many ways a linguistic innovator. ${ }^{19}$

In this essay I am specifically interested in Montagu's spelling variation and her use of preposition stranding, a stigmatized practice. The research material comes from the Bluestocking Corpus, which I have compiled from manuscript letters in the collections of the Huntington Library, British Library, and Houghton Library for the purposes of sociolinguistic research. My aim has been to create a representative sample of educated, genteel, eighteenth-century private writing within an ego-centered social network setting. The original texts have been reproduced as closely as possible for the requirements of linguistic research. ${ }^{20}$ At the time the studies of -ED spelling and preposition stranding were carried out, the corpus consisted of 218 letters by Montagu, approximately 150,000 words, between the 1730s and 1770s; for the section on modal verbs and other contractions, I had 243 letters, 183,0oo words, spanning from the 1730 s to the 1780 s. These transcriptions of 243 letters can now be accessed and downloaded at http://bluestocking.ling.helsinki.fi/.

Quite certainly, Montagu and most Bluestockings were not the primary target audience for grammars. The heyday of grammar writing began in the 1760 , when Montagu was already a published author. In the Bluestocking Corpus, the only

16. Raumolin-Brunberg, "Lifespan Changes," 190, 191-92.

17. John Edwards, Language and Identity (Cambridge, 2009), 21.

18. Ingrid Tieken-Boon van Ostade, The Bishop's Grammar: Robert Lowth and the Rise of Prescriptivism (Oxford, 2011).

19. Mel Evans, The Language of Queen Elizabeth I: A Sociolinguistic Perspective on Royal Style and Identity (Chichester, U.K., 2013).

20. Anni Sairio, Language and Letters of the Bluestocking Network: Sociolinguistic Issues in Eighteenth-Century Epistolary English (Helsinki, 2009), 52-69. I am deeply indebted to Elizabeth Eger for her edition Elizabeth Montagu, vol. 1 of Bluestocking Feminism: Writings of the Bluestocking Circle, 1738-1785, gen. ed. Gary Kelly (London, 1999). A selection of these letters edited by Eger were used in the first version of the corpus and subsequently checked against the originals in order to match the system I had developed for the corpus. 
reference to a language-related work concerns James Harris's Hermes: or, a Philosophical Inquiry concerning Language and Universal Grammar (1751), and Hermes is not a guidebook but a philosophical treatise on language. ${ }^{21}$ There was a fifteen-year gap between the publication of Hermes and Montagu's intention to read it; perhaps she was motivated by her scholarly pursuits at the time. She may have used grammars only as reference material that did not merit discussion. Certainly she was aware of the changing cultural atmosphere that all those texts reflect and toward which they contributed; this can be detected especially in her use of stigmatized and increasingly old-fashioned language features.

\section{- Private and Public Standards of Language}

By and large, published texts served as the norm for correct spelling in the early eighteenth century. During the seventeenth and early eighteenth centuries, contracted verbs were common in published texts, as Kari Haugland notes:

The appearance of a variety of contracted forms in the grammars and spelling books of this period is an indication that these forms were not considered entirely colloquial, epistolary or poetic, but were being established as legitimate variants even in scholarly prose. ${ }^{22}$

Printers' practices shifted toward greater uniformity in the course of the eighteenth century, but uniform spelling began to appear in private writing only toward the end of the century (if even then). Private writing retained so much variation that there is good reason to talk about two spelling systems. ${ }^{23}$

An extract from Montagu's Shakespeare essay and an extract of her personal letter illustrate the two standards of writing in the $1760 \mathrm{~s}$ :

The editor of Corneille's works, in terms so gross as are hardly pardonable in such a master of fine raillery, frequently attacks our Shakespear for the want of delicacy and politeness in his pieces: it must be owned, that in some places they bear the marks of the unpolished times in which he wrote, but one cannot forbear smiling to hear a critic, who

21. Elizabeth Montagu to Elizabeth Carter, 1766: "I am sorry I did not bring Mr Harris. I might scrape acquaintance with Hermes in this retirement, tho between the care of my health, vulgar business, \& attention to Shakespear, I can pretty well fill my day without reading more than is some way relative to my work." See also Elizabeth Montagu, ed. Eger, 170.

22. Haugland, "Is't allow'd or ain't it?" 179.

23. Larisa Oldireva Gustafsson, Preterite and Past Participle Forms in English 1680-1790: Standardisation Processes in Public and Private Writing (Uppsala, Sweden, 2002); Haugland, "Is't allow'd or ain't it?"; Noel Osselton, "Informal Spelling Systems in Early Modern English: 1500-1800," in English Historical Linguistics: Studies in Development, ed. N. F. Blake and Charles Jones (Sheffield, U.K., 1984), 123-37. 
professes himself an admirer of the tragedies of Corneille, object to the barbarism of Shakespear's. ${ }^{24}$

My spirits \& nerves suffer'd greatly from the agitation I was in during poor Lord Baths illness, \& the sad conclusion of it your Lordship will believe was not likely to repair the mischief I had received by suspense $\&$ anxiety. It is true that his great age might have prepared me for the misfortune, but as his health seem'd every year to improve, as he retain'd not only the solid \& strong faculties of his mind, but even the witt quickness \& vivacity of youth, it seem'd as if he was not internaly decay'd, tho fourscore years had made external marks \& impressions, nor indeed is there any reason to apprehend he sunk under the weight of years. ${ }^{25}$

The spelling in the first example reflects printers' input. It was not uncommon to give a printer responsibility over spelling, and Sarah Fielding and Robert Lowth expected their spelling to be corrected in the printing process. ${ }^{26}$ The printers who revised the spelling of the Shakespeare essay employed a fairly modern system of orthography. A comparison between the extant six pages of the final draft (in the collection of the Houghton Library, Harvard University) and the respective text in the first edition (accessed in Eighteenth Century Collections Online) reveals that the printers deleted extra initial capitals, expanded apostrophized variants into the emerging standard -ed form, and modernized certain variants, such as the -ick spellings (critick > critic). The orthographical differences between the draft, Montagu's private letters, and the finished product suggest that the scribe of the draft, whether it was Montagu or a trusted friend, had attempted to model the spelling after the system of printed texts but that the printers of this publishing consortium considered the outcome to be dated and revised the orthography. ${ }^{27}$

The second example represents Montagu's own spelling system. The letter contains contracted forms of past-tense verbs and past participles (seem'd, retain'd, decay'd), types that do not appear in the essay: long-establish'd in the draft has been expanded into long-established in the first edition. The spelling in Montagu's private letters does not entirely match the orthographical decisions made in the production of her essay, and on pages $642-43$, I show the changes she made in copying an extract

24. Montagu, Essay on the Writings and Genius of Shakespear (London, 1769), 4-5.

25. Montagu to [Charles Lyttelton], August 1, 1764, MS Eng 1351 (15-16), Houghton Library, Harvard University.

26. Ingrid Tieken-Boon van Ostade, "Standardization of English Spelling: The Eighteenth-Century Printers' Contribution," in Advances in English Historical Linguistics, ed. Jacek Fisiak and Marcin Krygier (Berlin, 1998), 458.

27. Anni Sairio, "Elizabeth Montagu's Shakespeare Essay (1769): The Final Draft and the First Edition as Evidence of Two Communities of Practice," in Communities of Practice in the History of English, ed. Joanna Kopaczyk and Andreas H. Jucker (Amsterdam, 2013), 177-97. 
from David Garrick's published ode into a letter she was writing to Lord Lyttelton. Nevertheless, the level of formality and significance of subject matter no doubt influenced the choice of spelling variants, and it is plausible that private and public standards were both present also in epistolary writing. ${ }^{28}$

\section{Effects of Normativity: Frowning upon Contractions}

In the 1710 and 1711 issues of the Tatler and Spectator, Jonathan Swift and Joseph Addison did not mince words about contracted spellings. Addison complained that the common omission of $e$ in drown' $d$, walk' $d$, and arriv' $d$ "has very much disfigured the Tongue, and turned a tenth part of our smoothest Words into so many Clusters of Consonants." Swift considered it a disgrace that the language was "overstocked with monosyllables." 29 According to Noel Osselton, Swift's “somewhat disorganized splutterings" should be interpreted as a reaction to the dual standard of spelling. 30 This early criticism did not have an immediate effect on contemporary usage. In 1740, George Fisher's Instructor still presents a pragmatic view of the usefulness of contractions and abbreviations: "To be ready in these, shews a Dexterity in Writing; and is very necessary for Dispatch." ${ }^{11}$ However, by the second half of the eighteenth century, contractions were increasingly condemned-sometimes for no reason and sometimes because they were considered to be harsh-sounding, colloquial, or even vulgar. ${ }^{32}$ The ideal of linguistic uniformity was strongly present at the time the Bluestocking circle was formed.

In grammars written by or after the mid-eighteenth century, contractions were declared "very destructive to Language" and "unnecessary" (Ann Fisher in 1753), 33 "intolerably bad" (George Campbell in 1776 on wasn't, didn't, shouldn't, and couldn't),34 "disrespectful and too familiar," and, as they were seen to indicate "ignorance and impudence," not to be used in letters to superiors (Alexander Bicknell in 1790).35 Campbell makes an exception with I'm, 'em, and -'d in past-tense verbs as "elision whereby the sound is improved," and he allows contractions in the familiar style, as they are "natural" in conversation. ${ }^{36}$

28. I am grateful to a reviewer of this essay for this observation.

29. Haugland, "Is't allow'd or ain't it?", 172; Albert C. Baugh and Thomas Cable,

A History of the English Language (Upper Saddle River, N.J., 2002), 260.

30. Osselton, "Informal Spelling Systems," $130-31$.

31. George Fisher, The Instructor, 5th ed. (London, 1740), 23.

32. Haugland, "Is't allow'd or ain't it?"

33. Ann Fisher, A New Grammar, with Exercises of Bad English, 3rd ed. (London, 1753), $117 \mathrm{n}$, emphasis in original.

34. George Campbell, The Philosophy of Rhetoric, 2 vols. (London, 1776), 2:404n.

35. Alexander Bicknell, The Grammatical Wreath; or, a Complete System of English Grammar (London, 1790), 135.

36. Campbell, Philosophy of Rhetoric, 2:404-5n. 
Book reviews of the 1770 s (in itself a publishing phenomenon of the mideighteenth century) 37 indicate that don't and won't had negative connotations and were perceived to reflect impoliteness, vulgarity, and a lack of education. In a 1774 issue of the Monthly Review, Hugh Kelly's play The School for Wives is criticized for putting "the affected style of a mincing milliner, or a coxcomb valet, into the mouths of people who are supposed to have enjoyed the advantages of education." 38 The usage of contractions was thus attributed to stereotypical social climbers such as the hairdresser, the valet, and especially the milliner.

Overall, this rising criticism focused on public rather than private writing. 39 While the emerging standard forms became increasingly common, private writing continued to display old-fashioned and criticized forms. Nonstandard language features may convey covert prestige and social identity, and they may be practical as well as familiar from spoken language practices, which explains why features labeled as old-fashioned and vulgar continued to be used. This brings us to the question of the social meaning of language.

\section{n The Social Meaning of Language}

When there is a choice between two or more linguistic variables (critic or critick? clogg'd or clogged? an initial capital letter or not?), the chosen form falls under scrutiny. Is it old-fashioned, refreshingly modern, or business as usual, the default form? Is it associated with learning, sophistication, or vulgarity? Factors that contribute to this evaluation include the social standing of the individual who uses the feature as well as the broader context, from social values and norms to participant roles, the register best suited for the communication situation, and the purpose of the communication. In this process, the language feature gains social meaning, which reflects upon the individual who uses it. $4^{\circ}$ A prestigious individual who habitually uses certain forms also produces social meaning for those features. ${ }^{41}$ Sometimes the decision stems from a practical reason, such as lack of time or writing paper, or the volume of correspondence, which may make shd or its superscripted companion, $s h^{d}$, more attractive variants than should. Some spelling variants may have had particularly loaded meanings during the latter half of the century, when the effects of the

37. Percy, "Mid-Century Grammars and Their Reception," 127.

38. Carol Percy, "The Social Symbolism of Contractions and Colloquialisms in Contemporary Accounts of Dr. Samuel Johnson: Bozzy, Piozzi, and the Authority of Intimacy," Historical Sociolinguistics and Sociohistorical Linguistics 2 (2002), http://www.let.leidenuniv .nl/hsl_shl/bozzy,\%2opiozzi1.htm. See also Percy, "How Eighteenth-Century Book Reviewers Became Language Guardians," in Social Roles and Language Practices in Late Modern English, ed. Päivi Pahta, Minna Nevala, Arja Nurmi, and Minna Palander-Collin (Amsterdam, 2010), 55-85.

39. Haugland, "Is't allow'd or ain't it?", 176.

40. See Mark Sebba, Spelling and Society: The Culture and Politics of Orthography around the World (Cambridge, 2007).

41. Penelope Eckert, "Variation and the Indexical Field," Journal of Sociolinguistics 12, no. 4 (2008): 453-76. 
normative tradition were kicking in. ${ }^{42}$ If contracted variants continue to be used by members of the highest echelons of society, then the questions of prestige and perhaps even standard itself become more complex. In what follows, I present three linguistic analyses of Montagu's correspondence to investigate these issues.

\section{Marking -ED: Fashion and Formality}

Orthographical variation may be inconspicuous, easily bypassed, and often normalized in editions, but it may also be structured and patterned following socially meaningful rules. David Garrick's ode, written in honor of the Shakespeare Jubilee in Stratford-upon-Avon in 1769, recommends Montagu's Essay to its readers:

As some news-paper writers have illiberally endeavoured to shake the poetic character of our immortal bard (too deeply rooted in the heart to be affected by them) it is recommended to those who are not sufficiently established in their dramatic faith, to peruse a work lately published, called, An Essay on the Writings and Genius of SHAKESPEARE, by which they will with much satisfaction be convinced, that England may justly boast the honour of producing the greatest dramatic poet in the world. 43

Garrick's compliment pleased Montagu considerably, and she copied this passage into her letter to Lord Lyttelton:

I was told ye other day that I had assisted Mr Garrick in his Ode. He has made the Author of the Essay a very handsome compliment in his preface to his Ode in these words. "As some news-paper writers have illiberally endeavoured to shake the poetick character of our immortal Bard, it is recommended to those who are not sufficiently establishd in their dramatick faith, to peruse a work lately publish'd, call'd an Essay on the writings, etc. by which they will with much satisfaction be convinced that England may justly boast the honour of producing the greatest dramatick poet in the World." As Mr Garrick must probably suspect who is the Author of this Essay, it was very handsome in him, as we have not been always the best friends. 44

42. Joan C. Beal has discussed the changing attitudes toward pronunciation and Larisa Oldireva Gustafsson to generational changes in orthography: Beal, "Prescriptivism and the Suppression of Variation," in Eighteenth-Century English: Ideology and Change, ed. Raymond Hickey (Cambridge, 2010), 21-37; Oldireva Gustafsson, Preterite and Past Participle Forms.

43. David Garrick, An Ode upon Dedicating a Building, and Erecting a Statue, to Shakespeare, at Stratford upon Avon (London, 1769), i, emphasis added.

44. Elizabeth Montagu to Lord Lyttelton, October 5, 1769, Elizabeth Robinson Montagu Papers, 1688-180o, MO 1468, Huntington Library, emphasis added. The Montagu papers at the Huntington are cited henceforward with the abbreviation MO. 
Perhaps Montagu copied from the original text when she wrote the letter; perhaps she had written it so many times that she knew the passage by heart. In either case, she changed some of the spellings. The -ic spellings (poetic, dramatic) were switched to the -ick form (championed by Samuel Johnson); lowercase letters were capitalized, perhaps for the sake of emphasis (bard $>$ Bard, world $>$ World); punctuation was slightly altered; and three -ed spellings were contracted (establishd, publish'd, call'd). Montagu did retain the spellings of endeavoured, recommended, and convinced. The text has thus shifted toward a less standardized, more informal, and varied style of private writing, and that Montagu made these changes suggests that the spelling variants in question have some kind of social meaning. 45

The -' $d$ and - $d$ variants of the regular past-tense verbs and past participles certainly carry social meaning. In late seventeenth- and early eighteenth-century letters, the absence or infrequent use of -' $d$ signals distance from contemporary printing styles. At that time, it was the most common contraction in public writing, but the increasing disapproval of contractions gradually eliminated it from print in the course of the century. In the last decades of the century, the absence of -' $d$ and the consistent use of - $e d$ in private writing indicates awareness of standard printing styles and, consequently, good education. Frances Burney's letters contain almost exclusively -ed forms, and the editors of Hester Lynch Thrale's letters mention that she came to see elision as outmoded. ${ }^{46}$ Larisa Oldireva Gustafsson considers the consistent absence of -' $d$ to be the "hallmark of the new spelling style," and Tieken-Boon van Ostade suggests that Lowth's frequent use of -' $d$ ( 78 percent of all variants) in his letters to his wife is an indicator of informal language use, particularly as in one instance, the $e$ has been struck out: this contraction does not appear in Low th's most formal letters. 47 The unapostrophized - $d$ is a feature of private writing, rarely used in printed text, not commented on by grammarians, and possibly a sign of informality. 48

In the following I analyze the range of -ED spellings in Montagu's letters from the 1730 s to the late 1770 s. The variation and co-occurrence of these forms is illustrated by the following three examples:

45. Sairio, Language and Letters of the Bluestocking Network, 225.

46. Oldireva Gustafsson, Preterite and Past Participle Forms, 54-58, 224-26, 228; Tieken-Boon van Ostade, "Standardization of English Spelling," 466-67; The Piozzi Letters, vol. 4, 1805-1810, ed. Edward A. Bloom and Lillian D. Bloom (Newark, N.J., 1997), 53.

47. Oldireva Gustafsson, Preterite and Past Participle Forms, 260; Ingrid TiekenBoon van Ostade, "Edward Pearson Esqr: The Language of an Eighteenth-Century Secretary," in Business and Official Correspondence: Historical Investigations, ed. Marina Dossena and Susan Fitzmaurice (Bern, 2006), 137. See also Ingrid Tieken-Boon van Ostade, "'Disrespectful and Too Familiar?' Abbreviations as an Index of Politeness in 18th-Century Letters,' Syntax, Style, and Grammatical Norms: English from 1500-2000, ed. Christiane Dalton-Puffer, Dieter Kastovsky, Nikolaus Ritt, and Herbert Schendl (Bern, 2006), 229-47.

48. Oldireva Gustafsson, Preterite and Past Participle Forms, 172. 
I flatter myself your Lordship was as much mistaken when you complain'd of decay of health as I am sure you was when you talk'd of the failure of your mental faculties it was happy for me you join'd them together, as my confidence in the latter, guarded me a good deal against the apprehensions of the former. (Montagu to Lord Bath, [ca. March 18, 1760], MO 4500)

I $c^{d}$ not send you any partridges for ye snow last year destroyd them in a cruel manner, \& we have yet got but a brace which were kill'd on saturday. A Voracious fox destroy'd us nine Turkeys on saturday last. (Montagu to Sarah Scott, September 4, [1768], MO 5898)

I am sorry to tell you that a friend of yours is no longer a conceal'd scribbler. I had better have employd the Town Cryer to have proclaimed me an Author, but being whisperd it has circulated with incredible swiftness. 49

The choice of spelling variant may, of course, be determined by the practicalities of space and time. Letters were often written in a hurry. And in the transcription process, the researcher may fail to notice apostrophes that are extremely faded or marred by a tear in the paper. However, the larger the numbers, the more reliable the analysis: there are over 2,600 -ED forms in Montagu's letters, which should make up for the transcriber's mistakes and the contexts of letter writing.

Montagu's most common choices are the full - $e d$, the apostrophized -' $d$, and the simple $-d$. Apostrophized and unapostrophized - $t$ variants (stopt, vex't) are very infrequent. Figure 1 shows how these variants appear in Montagu's private letters in the course of four decades (see table 1 in the appendix for the raw numbers).

Montagu's response to the trend toward uniform spelling is lukewarm: in forty years, -ed increases moderately from 62 percent (277 out of 444 ) to 68 percent ( 360 out of 529 ). $5^{\circ}$ It is clear that contractions were an inherent part of her private language use. However, she was also aware of the diminishing popularity of -' $d$ and its loss of status as a marker of sophistication. The apostrophized variant, which comprised 35 percent (156) of Montagu's -ED spellings in the late 1730 s and early 1740 s, drops to 9 percent (48) by the end of the 1770 . Significantly, Montagu did not switch from -' $d$ to the emerging standard. She simply dropped the apostrophe, so that $-d$, the form characteristic of private language use and rarely mentioned by grammarians, took over. That Montagu did not switch to - ed suggests that there was no need for such formality: the $-d$ variant became significantly more common over the years, which fol. 112 .

49. Montagu to Lord Lyttelton, December 23, [1769?], British Library, Add. MS 42087,

50. Sairio, Language and Letters of the Bluestocking Network, 234. 


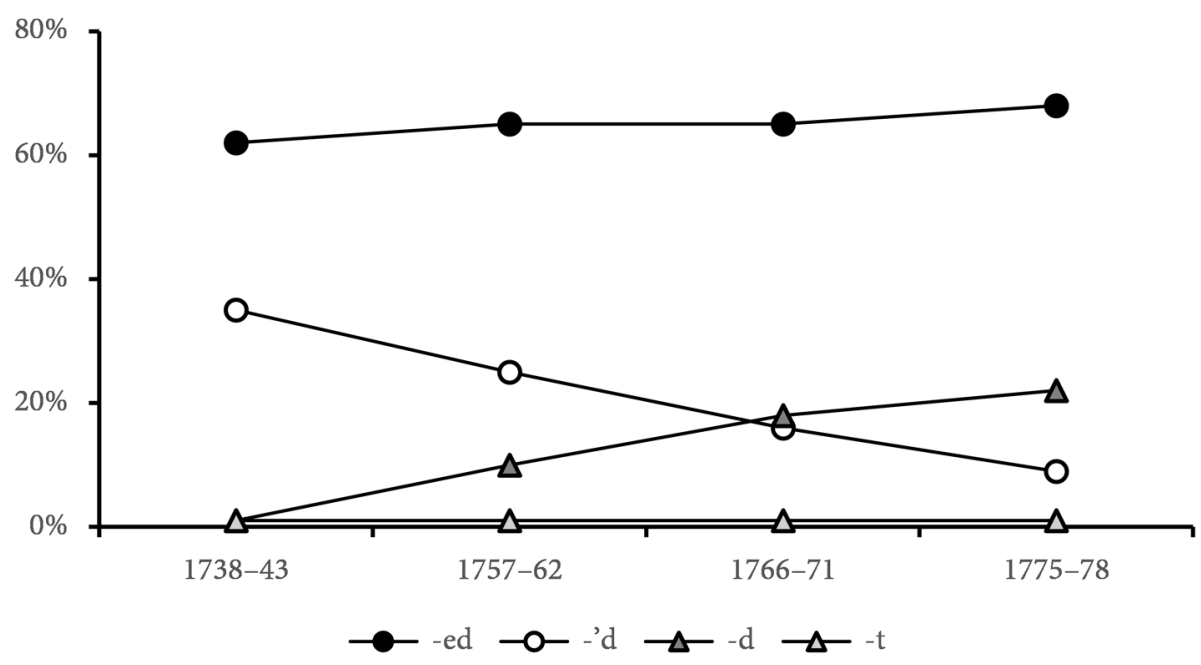

FIGURE 1. -ED spelling variation in Montagu's private letters, 1738-78.

indicates growing familiarity in those social circles. It seems that Montagu began to avoid the apostrophized variant around the time she published for the first time in Lyttelton's Dialogues of the Dead, and she continued to avoid it when the Shakespeare essay appeared. She did not discard -' $d$ altogether, and the first six pages of the essay draft in the Houghton Library (whoever its scribe) include five -' $d$ forms. ${ }^{51}$ At first, Montagu's - $d$ spellings seem to center in family correspondence, but by the late 1770s, $-d$ has become an established part of her spelling pattern.

The choice of -ED variant is influenced by the recipient's gender. The -' $d$ variant appears significantly more often in Montagu's letters to men ( $\mathrm{p}<0.01$ in the chisquare test), and $-d$ in her letters to women $(\mathrm{p}<0.001) .5^{2}$ There is a significant increase of - $d$ spellings in letters to women between 1757-62 and 1766-71 ( $\mathrm{p}<0.001)$ and in letters to men as well $(\mathrm{p}<0.025)$, which indicates that the 1760 s were important in terms of changes in Montagu's spelling. The contractions may have social meanings that the relatively neutral standard variant probably lacks: -' $d$ reflected printers' practice in the beginning of the century, it was frequently used in published books at the time Montagu was learning to read and write, and it was therefore a familiar form for her and her contemporaries. Even though Montagu reacted to the outmodedness of

51. Sairio, "Elizabeth Montagu's Shakespeare Essay (1769)," 189.

52. Sairio, Language and Letters of the Bluestocking Network, 243. The chi-square test can be used to detect whether a finding is the result of random variation or reflects a genuine difference between two or more objects of study. The cutoff point between significant and random variation is usually 0.05 , so that chi-square values of $0.025,0.01$, and 0.001 indicate significant variation. 
this variant, it might have still have retained some of its old prestige. That - $d$ is much more frequent in Montagu's letters to women (Sarah Scott, Elizabeth Carter, Frances Boscawen, Elizabeth Vesey, and others) is perhaps due to its informal connotations and the network effect. It did not necessarily have gendered nuances; for example, poet William Mason (1724-1797) preferred - $d$ over all the other -ED variants in his letters to Thomas Gray. 53 In comparison, Montagu's husband, Edward Montagu, did not use $-d$ at all and preferred the apostrophized variant. There simply was a lot of permissible idiolectal variation in eighteenth-century letter writing.

Age mattered, too. Montagu's more senior correspondents, Lord Bath (b. 1684), Edward Montagu (b. ca. 1691), Elizabeth Robinson (b. ca. 1693), and Benjamin Stillingfleet (b. 1702), used the emerging standard -ed significantly less (it makes up 56 percent of all the variants combined) and the contractions significantly more than the younger letter writers, George Lyttelton (b. 1709), the Duchess of Portland (b. 1715), Elizabeth Vesey (b. ca. 1715), Montagu herself, Frances Boscawen (b. 1719), and Sarah Scott (b. 1720), in whose letters -ed stands for 65 percent of all the variants. 54 Elizabeth Montagu spelled significantly more with the emerging standard variant than her husband, whereas Edward Montagu used -'d significantly more than she $(\mathrm{p}<0.001)$. Oldireva Gustafsson has shown that Lady Sarah Lennox (b. 1745) chose -ed almost every time ( 94 percent) when she wrote to her sister in 1781-84; in Montagu's and Scott's correspondence in the late 1770s, -ed spellings make up only 69 percent of the variants. 55 Lennox was a generation younger, so she learned to write in the 1750 s and had, perhaps, been young enough to study grammars in the 1760 s. Montagu and Scott, on the other hand, were quite comfortable using contracted verbs. Lennox and Burney represented the new standard, and Montagu and Scott followed the old norms of private spelling.

Besides practical aspects and sociolinguistic factors, pronunciation also affected the choice of -ED variant. The final $<\mathrm{e}>$ is not pronounced in any of the contractions in the Bluestocking Corpus. Of the lexemes that take the -ed form, approximately 40 percent would be pronounced with the final $<$ e $>$ in present-day English. This explains why -ed rarely replaces a contraction and why certain verbs in the Bluestocking Corpus are not spelled in the full form: spelling marks the deletion of the final $<\mathrm{e}>$. None of the sixteen verbs spelled with all three variants (answer, ask, beg, call, happen, swell, alarm, appear, bestow, call, establish, honour, mention, ruin, suffer, inform) are pronounced with $<\mathrm{e}>.56$

What about the -ic/-ick variation, then? In her copy of Garrick's introduction, Montagu changed poetic and dramatic into poetick and dramatick, and a corpus

53. See Correspondence of Thomas Gray, ed. Paget Toynbee and Leonard Whibley, 3 vols. (Oxford, 1935).

54. Sairio, Language and Letters of the Bluestocking Network, 305.

55. Sairio, Language and Letters of the Bluestocking Network, 254; Oldireva Gustafsson, Preterite and Past Participle Forms, 116-17.

56. Sairio, Language and Letters of the Bluestocking Network, 260-61. 
analysis of her letters shows that she indeed favored -ick consistently and increasingly over the years. Compared to the eighteenth-century section of the Corpus of Early English Correspondence (CEEC, 4,90o letters of 2.2 million words from 1680 to 1800 ), this makes Montagu rather conservative. 57 When we look at the baseline data provided by CEEC, -ick is the dominant spelling in the first half of the eighteenth century, with a frequency of 70 percent (125) in 1700-24 and 67 percent (125) in 1725-49. But after midcentury, -ick takes a nosedive and -ic becomes the default spelling ( 72 percent [319] in $1750-74,80$ percent [556] in 1775-1800). This coincides with the onset of high-frequency language codification. What happens in Montagu's letters in the Bluestocking Corpus is almost the opposite. In the letters of her youth in the 1730 and 1740 s, $-i c$ reaches its highest level with 13 percent, but there are only four hits. The -ick spellings at this time make up 87 percent (26) of the usage. In the 1750 s and 1760 s, when the Bluestocking activities began to be in full swing, Montagu favors -ick with 89 percent (141), and in the 1770 os and 1780 s, her letters include only -ick forms (10o percent, 31). Some words often take both spellings until the latter period (music, poetic, public, tragic), but a wider range of words are used with -ick. Montagu experimented with the upcoming -ic in her youth but discarded it for the form that was dominant in the first half of the eighteenth century, and she stuck with that spelling even though it was going out of style.

\section{Modals, Articles, Conjunctions, and Letter-Writing Practices}

In a letter of 1776 , Montagu had this to say about fashionable fops and the women they harassed:

But the Lady who ever she is, shd have shewn a sullen contempt of ye affront rather than anger, \& never again have ventured into such rude society. Really ye maccaronies wd be more troublesome than fleas $\&$ flies in a hot climate if they were allow'd to [fix?] upon a Ladys lips whenever they pleased. I suppose there is not one Maccaroni in a hundred that could muster up might for a smack. (Montagu to Elizabeth Vesey, May 2, 1776, MO 6476)

Spelling may not be the most immediately interesting topic in this passage, but I want to draw attention to the co-occurrence of the and ye, the use of the ampersand, and full and contracted modals (shd, wd, could). The contracted forms of the negative modals cannot, shall not, will not, and the auxiliary do not change the verb phrase

57. The Corpus of Early English Correspondence is compiled of edited letter collections, and even though the spelling in the editions was a key criterion in the selection process, orthographical assessments need to be made with caution. However, even though all original spellings may not be reproduced in the corpus collections, when spelling variation appears in these letters, it is likely that it was present also in the original manuscripts. See http://www .helsinki.fi/varieng/CoRD/corpora/CEEC/index.html. 


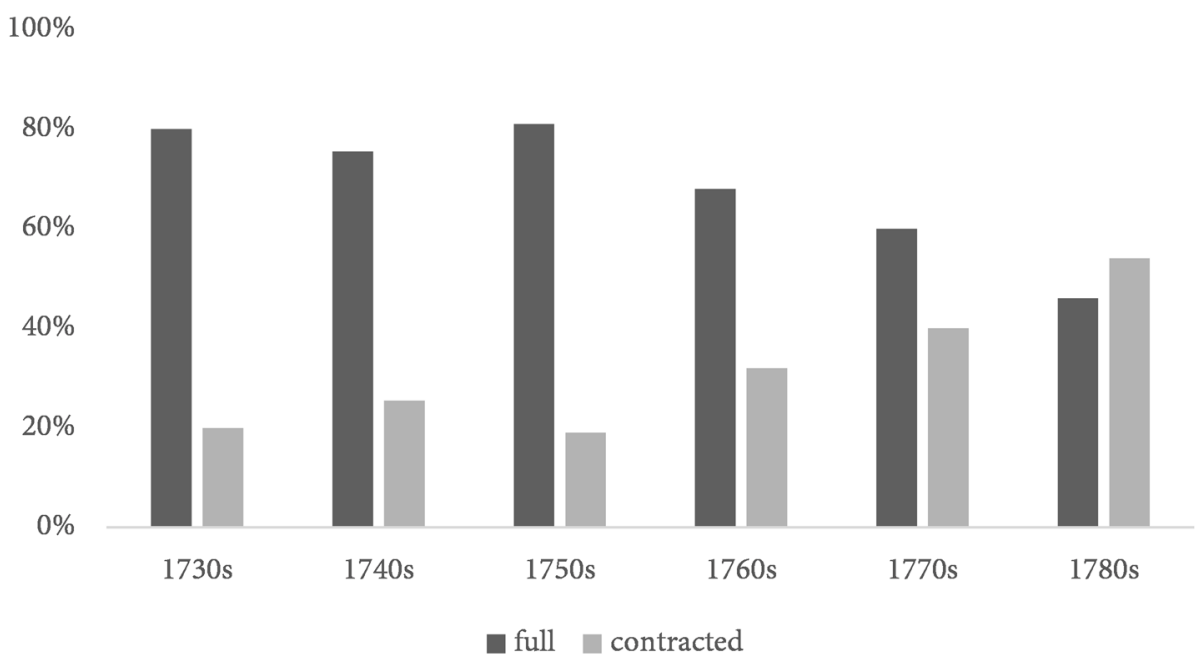

FIGURE 2. Full and contracted modals and auxiliaries in Montagu's letters.

itself (cannot $>$ can't), whereas positive/tentative modals could, should, and would had a range of spellings, from the apostrophized (cou'd) to the most abbreviated forms $(c d, w d)$, which did not affect pronunciation. In this section I examine the variation in modal and auxiliary verbs, the conjunction pair and/er, the definite article the/ $y e$, and the possessive pronoun your $(s) / y r(s)$ in order to assess diachronic and sociolinguistic variation and change in the use of high-frequency spelling variants. Figure 2 shows what happens in the modal spellings in the course of five decades; see also table 2 in the appendix.

From the 1760 s onward, Montagu increased her use of contractions until the 1780 s, when they actually surpassed the full spellings. In this respect, Montagu's spelling seems to have been at its most formal during her youth, the early years of her marriage, and the early Bluestocking years. Her youth and relatively dependent social position may have brought about particularly careful spelling (even though her choice of topic and self-expression was sometimes flippant and bold, particularly in the early letters to the Duchess of Portland), and the same orthographical attentiveness can be observed in the early Bluestocking era. While her increasing avoidance of the once sophisticated -' $d$ may have been boosted by her literary accomplishments, ventures into authorship are not similarly visible in Montagu's use of modals and the auxiliary do not. In a sense the situation is reversed, and Montagu was at her most informal after the essay was published. However, when the negative modals are separated from could, would, and should, it becomes apparent that the increase in contractions is solely due to the tentative modals. The negative contractions, scornfully attributed to valets and milliners in the 1770s, are actually in steep decline (fig. 3). 


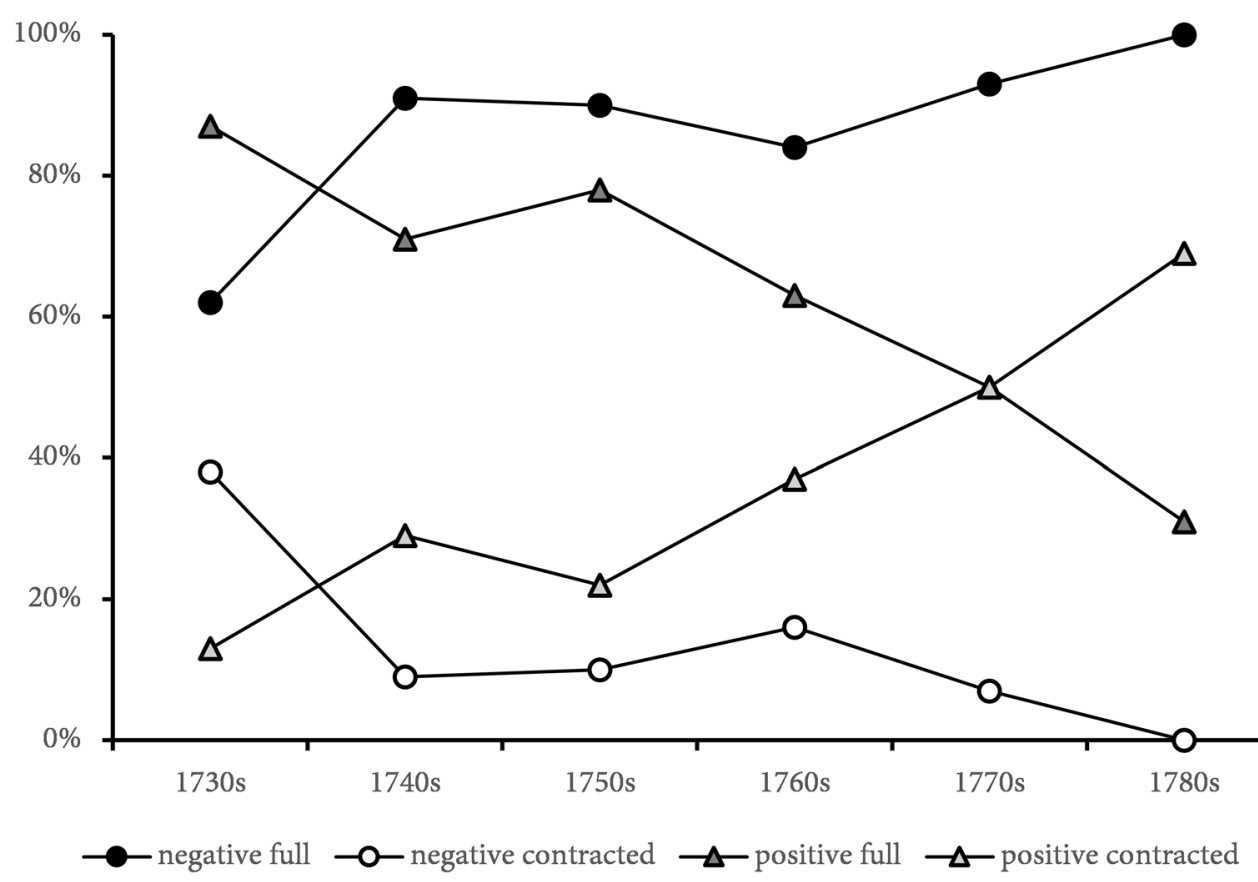

FIGURE 3. Full and contracted modals and auxiliaries, positive and negative.

Beginning in the 1750 s, Montagu reduces her use of can't, won't, and don't ("negative contracted" in fig. 3), perhaps reacting to their impolite and vulgar connotations. However, could, should, and would ("positive full") decrease from the 1750 s onward, and in the 1770s, she switches from the full forms to the respective abbreviations ( $c d$, shd, wd; "positive contracted"). According to Tieken-Boon van Ostade, modal contractions start appearing in Jane Austen's letters as late as 1817, when she was in her forties; Montagu followed the same age-related pattern..$^{8}$ These possibly rather neutral modal contractions fell out of use probably sometime in the nineteenth century, but the negative contractions persisted against the proscriptive attitudes and continue to thrive. This is most likely because don't, won't, and can't are independent forms of both spoken and written language and therefore more resistant to spelling uniformity than variants like shd, which only exist in a written form.

Gender, again, played a key role. Montagu used contracted verbs significantly more when she wrote to women $(\mathrm{p}<\mathrm{0.001})$, and full spellings when she wrote to men

58. Ingrid Tieken-Boon van Ostade, In Search of Jane Austen: The Language of the Letters (New York, 2014). 


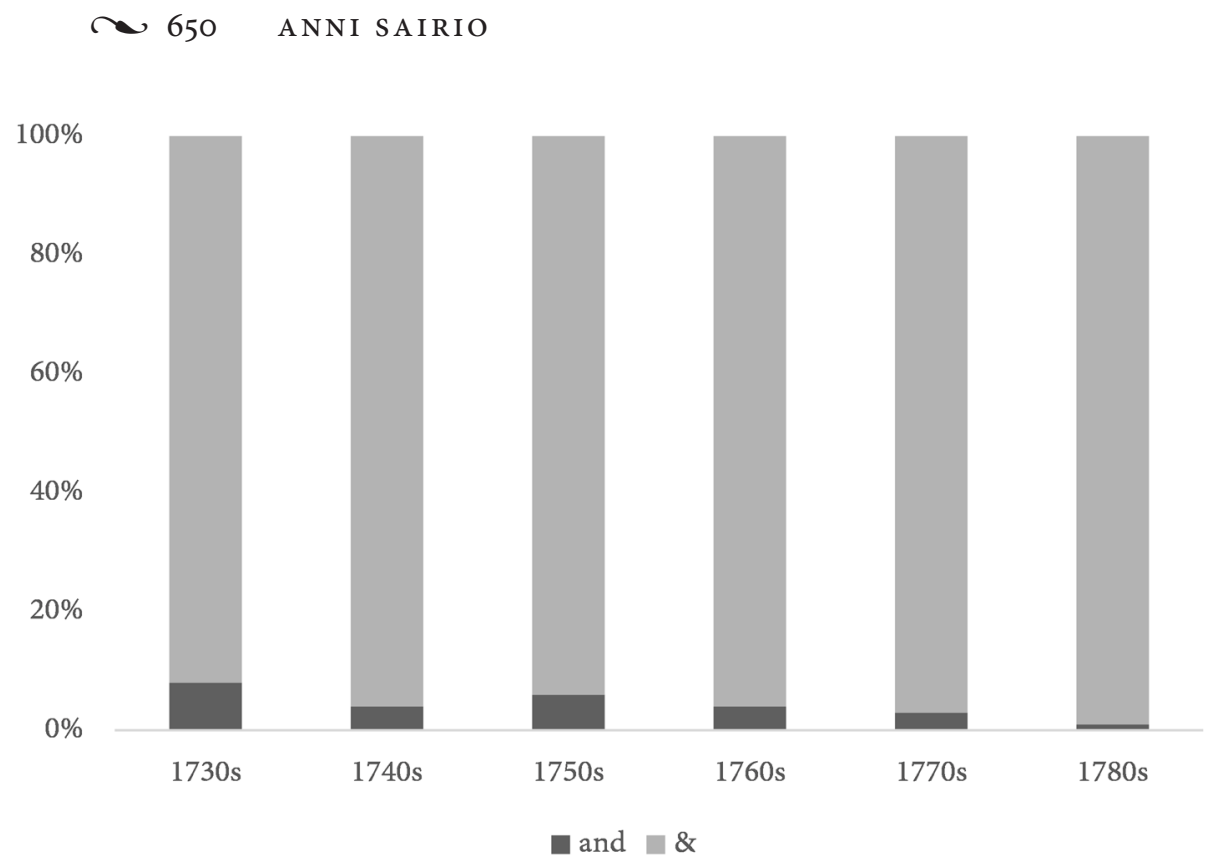

FIGU RE 4a. Change in conjunctions and vs. \&, 1730s-1780s.

( $\mathrm{p}<0.001) .59$ Consequently, her style was more informal and speechlike when her recipient was a woman, and more formal with men. But compared to Scott, Boscawen, Vesey, and the Duchess of Portland, Montagu was the only woman who used full forms more than contractions. With such a small selection of data, it is difficult to assess the norms in this circle, but on the continuum of linguistic formality, Montagu appears to be more correct, as it were, than her female friends and family. Montagu's language also reflects an awareness of differences in rank, as she is particularly careful to spell with full lexemes when the recipient is a social superior. ${ }^{60}$ Familiarity and intimacy on the one hand and formality and distance on the other affect the use of these verbs.

Figures $4 \mathrm{a}-\mathrm{c}$ show the diachronic variation in the spelling of and/dr, thelye, and the possessive pronoun $\operatorname{your}(s) / y r(s)$, often used as a semiformulaic feature of letter writing (your Lordship, your Grace, yr letter).

It is easy to see simply from browsing through the letters that contractions were always a part of Montagu's spelling repertoire, but corpus analysis shows that over time, she increased her usage of all of these contracted forms. Montagu's letters show a consistent and nearly categorical preference of the ampersand, which makes

59. Sairio, Language and Letters of the Bluestocking Network, 276-77.

60. Sairio, Language and Letters of the Bluestocking Network, 278. 
SOCIOLINGUISTIC VARIATION IN MONTAGU'S LETTERS 651

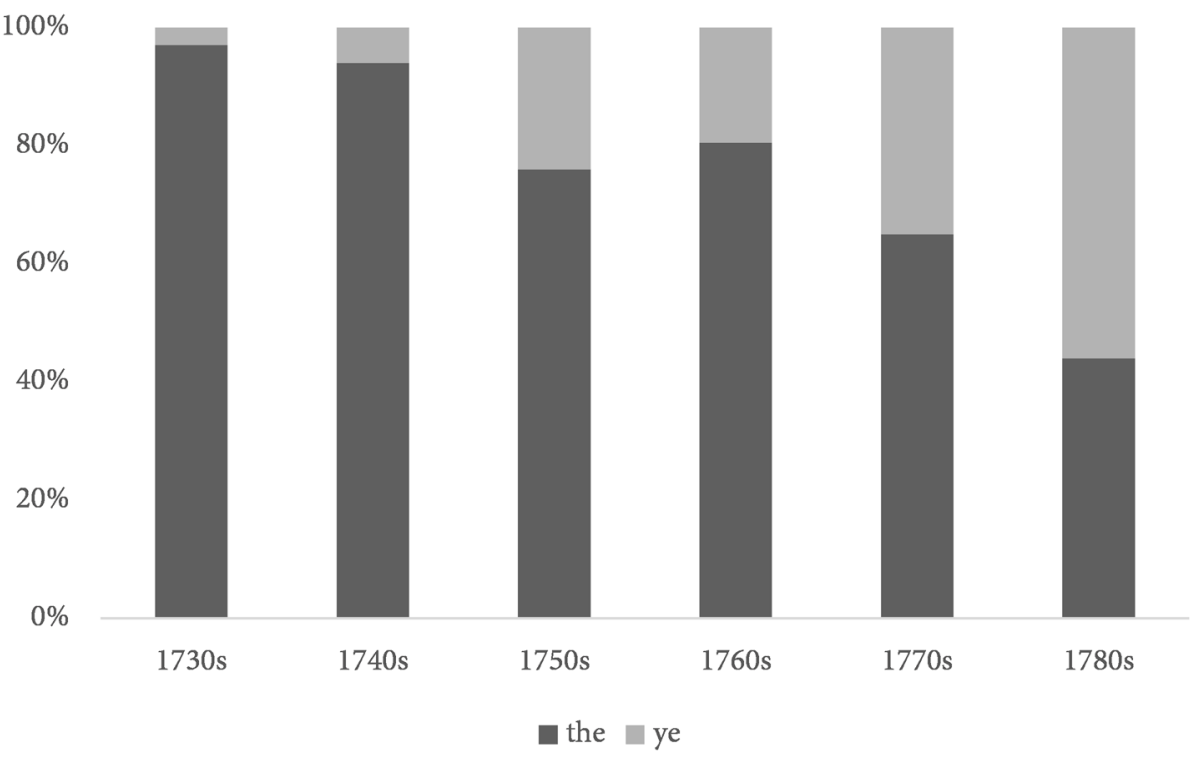

FIGURE 4b. Change in definite articles the vs. ye, 1730s-1780s.

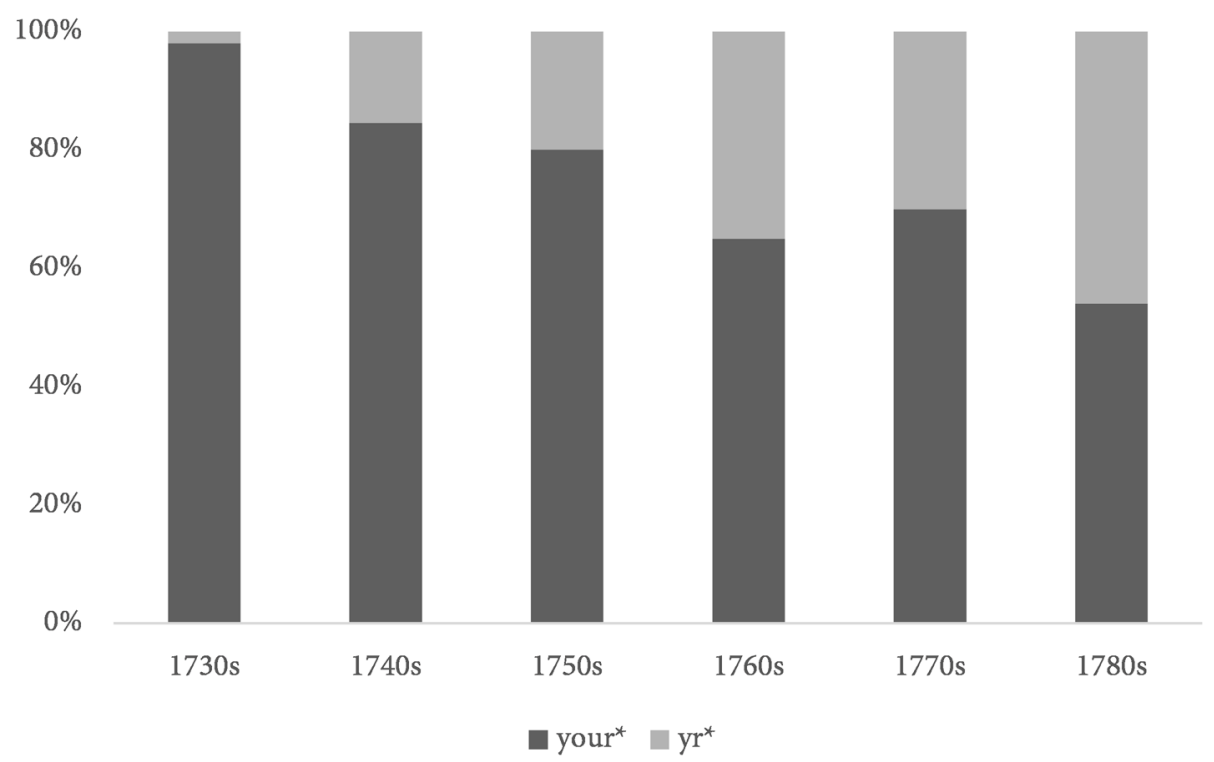

FIGURE 4c. Change in second-person possessive pronouns your(s) vs. yr(s), 1730 s -178 os. 
the conjunction and somewhat more marked, and she increased her usage of both $y e$ and $y r$ significantly from the 1730 s to the 1780 os. This variation is not connected to sociolinguistic factors: it is part and parcel of Montagu's letter-writing style, independent of her social relationship with the recipient.

\section{$\sim$ True Stigma: Preposition Stranding}

As noted, contracted spellings were frequent in published texts in the early eighteenth century, and subsequently more or less legitimate in private writing. Despite the criticism, they continued to be used because of their practical and speechlike qualities, and because they were an inherent part of private writing. The situation is very different when it comes to another language feature that grammarians and rhetoricians regarded with remarkable unease (although not with uniform opposition). Preposition stranding was highly stigmatized in eighteenth-century accounts of language. Below are some of the few occurrences of this construction in Montagu's letters.

Sometimes preposition stranding is grammatically required and cannot be replaced without altering the structure of the clause, for example in the passive construction in the third example below. Some, particularly the wh-relative clause constructions, may be changed into the so-called "pied piping" construction, in which the preposition is moved to accompany its head word. ${ }^{61}$ The first two examples would allow this option (My Father with whom I was, of which I am very glad):

My Father who I was with this morning assures me he has orderd Mr Parker to charge his Tenants to [ask?] for Sir Thos Clavering. (Elizabeth Montagu to Edward Montagu, [December 6, 1758], $\mathrm{MO} 2360$ )

My Brother Morris \& his family are going to Sandleford, which I am very glad of, for I think it is a Good air for ye sweet little man. (Montagu to Sarah Scott, [June?] 22, [1760], MO 5779)

Rousseau is at Chiswick, he left London because he $\mathrm{w}^{\mathrm{d}}$ not be gazed at. (Montagu to Elizabeth Vesey, February 1, 1766, MO 6386)

I hope my Neices will never stand still to be made love to before a numerous audience. (Montagu to Mary Robinson, [1771], BL, Add. MS 40663 , fol. 21)

61. For an account of preposition stranding and its characteristics in present-day English, see Rodney D. Huddleston and Geoffrey K. Pullum, The Cambridge Grammar of the English Language (Cambridge, 2002), 627. 
An earlier study of preposition stranding in Montagu's letters shows that there are altogether ninety-one instances of this feature, both obligatory constructions and those that allow for the possibility of pied piping. ${ }^{62}$ This is not much, so what follows is a somewhat tentative analysis. Preposition stranding in Montagu's letters decreases considerably from the 1730 s to the late 1770 s $(33 \rightarrow 26 \rightarrow 26 \rightarrow 6)$, and its decline begins from the 1750 on onward. She increasingly avoids all types, so that the grammatically required forms also become rarely used. The great majority of stranded prepositions represent the obligatory categories, whereas in $w$ h-relative clauses, preposition stranding is practically nonexistent $(5 \rightarrow 6 \rightarrow 2 \rightarrow 0)$. Gender and social class have no influence here-stigma controls usage, and social ascent does not neutralize the impact of that stigma. In a letter Montagu wrote to Elizabeth Carter in 1778, we find the following correction:

My health \for/ which you so kindly interest yourself, has not been affected by the [TEAR] humours of april tho they have rarely been more changeful or severe. (April 24, 1778, MO 3444)

The insertion of for before the relative pronoun which suggests that Montagu may have corrected a case of preposition stranding. It is possible that she reacted to the comments of rhetoricians who derided preposition stranding as "enfeebling and degrading." 63 However, that she avoided preposition stranding before the normative tradition actually took off in the 176 os suggests that she was ahead of the prescriptivists. This supports Nuria Yáñez-Bouza's argument that the normative tradition did not trigger the decreasing use of preposition stranding in the English language but merely reinforced an existing trend. ${ }^{64}$ In the 1750 s, Montagu was at the early stages of her career as a Bluestocking salonnière, and her awareness of the linguistic norms of correctness was probably intensified. When Dryden, a frequently cited authority in eighteenth-century grammars, states that the preposition at the end of Jonson's verse “The Waves, and Dens of beasts cou'd not receive / The bodies that those souls were frighted from" is "a common fault with him, and which I have but lately observ'd in my own writings," 65 an individual with literary ambitions may find themselves agreeing. ${ }^{66}$ Furthermore, given that grammarians such as Lowth

62. Sairio, Language and Letters of the Bluestocking Network, 201.

63. Hugh Blair, Lectures on Rhetoric and Belles Lettres, 3 vols. (Dublin, 1783), 1:285; see also Henry Home, Lord Kames, Elements of Criticism, 6th ed. (Edinburgh, 1785).

64. Nuria Yáñez-Bouza, "Preposition Stranding and Prescriptivism in English from 1500 to 1900: A Corpus-Based Approach" (PhD thesis, Manchester, 2007), 277. See also Yáñez-Bouza, Grammar, Rhetoric, and Usage in English: Preposition Placement 1500-1900 (Cambridge, 2015).

65. John Dryden, "Defence of the Epilogue," in The Conquest of Granada by the Spaniards (London, 1672), 165-66.

66. Susan Wright, "The Critic and the Grammarians: Joseph Addison and the Prescriptivists," in Towards a Standard English, 1600-180o, ed. Dieter Stein and Ingrid Tieken-Boon van Ostade (Berlin, 1994), 243-84; Yáñez-Bouza, "Preposition Stranding and Prescriptivism," 207. 
looked to the upper classes for the norms of correct language but did not represent that class themselves, this early genteel avoidance of preposition stranding may have been recognized and authorized by the eighteenth-century grammarians as correct language use. Montagu may not be reacting to the atmosphere against preposition stranding but creating it, and norms like these may have been negotiated between the upper classes and the grammarians. The "learned" and the "polite" could have thus contributed to the doctrine of correctness. ${ }^{67}$

\section{Conclusion}

In a sociolinguistic analysis of Montagu's personal letters, complex links emerge between language change, social relationships, gender, and the normative tradition. Montagu's letters of the late 1750 s and 1760 s testify to considerable linguistic changes that may reflect her increasing social influence and her ventures into authorship, blossoming Bluestocking friendships, and emerging eighteenth-century prescriptivism. Some of these changes indicate increasing informality in the epistolary style, whereas others display awa reness of language norms. These findings also suggest language change in the context of transition from one social network to another: from her relatively dependent position in her family sphere and the Portland circle as young Fidget to her later, central membership in the Bluestocking network, eventually resulting in the grandiose title "Queen of the Blues."

It is possible to find a great deal of social meaning in eighteenth-century spelling variation, and the field of orthographical sociolinguistics provides a useful framework. ${ }^{68}$ Overall, contractions in the Bluestocking Corpus are significantly more common in family correspondence, in letters written by women to women, and correspondence between social equals. ${ }^{69}$ Montagu was not very concerned with the emerging dominance of -ed in public writing, and evidently did not consider spelling-related prescriptive trends particularly important in her epistolary style. Perhaps she had the luxury of indifference toward new linguistic proscriptions that did not seem relevant in private writing practices. It is also possible that, for example, the use of full spellings remains relatively stable in an idiolect once a system has been learned. As for preposition stranding, Montagu may have internalized the stigma that derived from the seventeenth century. Preposition stranding in its many forms, though a perfectly valid and useful construction with a long history in the English language, seems to have been on its way out of Montagu's language as her social status became more prominent.

67. Sairio, Language and Letters of the Bluestocking Network, 210-11, Yáñez-Bouza, "Preposition Stranding and Prescriptivism," 277.

68. Mark Sebba, Spelling and Society; Orthography as Social Action: Scripts, Spelling, Identity, and Power, ed. Alexandra Jaffe, Jannis Androutsopoulos, Mark Sebba, and Sally Johnson (Boston, 2012).

69. Sairio, Language and Letters of the Bluestocking Network, 302. 
Contractions were an essential part of Montagu's epistolary spelling, and their high frequency suggests language stability rather than innovative tendencies. Judging from her preference for -ick and - $d$, Montagu was indeed a conservative speller. She appears to have been a fast, economical writer with her categorical preference for $c d$, shd, and $w d$ and their superscripted forms. Overall, her spelling was more formal and perhaps closer to the public standard than Scott's, Vesey's, Portland's, or Boscawen's, but over the years her style seems to have become more casual and speechlike. A linguistic biography builds upon the connection between idiolect and social identity, a topic that I have previously discussed in the context of verbal irony, literary references, and female learning in Montagu's and the Duchess of Portland's early correspondence, and in Montagu's linguistic constructions of self-discipline. ${ }^{70}$ Montagu's spelling resembles her male correspondents' more formal style in many ways, and her prominent, increasingly public social standing and reputation for learning might account for some of this. As the Queen of the Blues, whose letters were read also for their literary value, Montagu undoubtedly felt obliged to maintain certain standards, but the weights and measures she responded to were to some extent of her own choosing.

I am very grateful for the valuable comments made by the journal's reviewers.

ANNI SAIRIO holds a Docentship in English Philology at the University of Helsinki, and her background is in historical sociolinguistics of eighteenthcentury English. She has edited Bluestocking correspondence (available at http://bluestocking.ling.helsinki.fi/) and carried out several corpus-linguistic studies of language variation and change in the Bluestocking circle. Her research interests include language and social identity, spelling variation, editing letters, corpus compilation, and historical non-native English.

70. Anni Sairio, "Cordials and Sharp Satyrs: Stance and Self-Fashioning in EighteenthCentury Letters," in Touching the Past: Studies in the Historical Sociolinguistics of Ego-Documents, ed. Marijke van der Wal and Gijsbert Rutten (Amsterdam, 2013), 183-200; Sairio, "Scripts of Self-Discipline and the Linguistic Biography of Elizabeth Montagu" (paper, The Eighteenth Century in Ego Documents conference, University of Zurich, March 9-10, 2017). The latter draws on Paula R. Backscheider's Elizabeth Singer Rowe and the Development of the English Novel (Baltimore, 2013). 
$\sim 656$ ANNI SAIRIO

\section{Appendix}

TABLE 1. Percentage [number] of -ED variations in Montagu's letters, $1738-78$

\begin{tabular}{lcccccccccc}
\hline & -ed & & -'d & & -d & & -t & & \multicolumn{3}{c}{ Total } \\
\hline $1738-43$ & 62.4 & {$[277]$} & 35 & {$[156]$} & 1.4 & {$[6]$} & 1.1 & {$[5]$} & 100 & {$[444]$} \\
$1757-62$ & 64.7 & {$[496]$} & 24.6 & {$[189]$} & 10 & {$[77]$} & 0.7 & {$[5]$} & 100 & {$[767]$} \\
$1766-71$ & 65.3 & {$[602]$} & 16.1 & {$[148]$} & 17.9 & {$[165]$} & 0.8 & {$[7]$} & 100 & {$[922]$} \\
$1775-78$ & 68.1 & {$[360]$} & 9.1 & {$[48]$} & 22.3 & {$[118]$} & 0.6 & {$[3]$} & 100 & {$[529]$} \\
\hline Total & 65.2 & {$[1,735]$} & 20.3 & {$[541]$} & 13.7 & {$[366]$} & 0.8 & {$[20]$} & 100 & {$[2,662]$} \\
\hline
\end{tabular}

TABLE 2. Percentage [number] of full and contracted modals and auxiliaries in Montagu's letters

\begin{tabular}{|c|c|c|c|c|c|c|}
\hline & $1730 \mathrm{~s}$ & $1740 \mathrm{~s}$ & $1750 \mathrm{~s}$ & $1760 \mathrm{~s}$ & $1770 \mathrm{~s}$ & $1780 \mathrm{~s}$ \\
\hline negative full & 62 [29] & $91 \quad[42]$ & $90 \quad[79]$ & 84 [145] & $93 \quad[63]$ & $100[21]$ \\
\hline $\begin{array}{l}\text { negative } \\
\text { contracted }\end{array}$ & $38 \quad[18]$ & [4] & [9] & $16 \quad[27]$ & [5] & {$[0]$} \\
\hline positive full & 87 [109] & $71 \quad[103]$ & $78 \quad[220]$ & 63 [311] & $50 \quad[111]$ & $31 \quad[22]$ \\
\hline $\begin{array}{l}\text { positive } \\
\text { contracted }\end{array}$ & 13 & $29 \quad[43]$ & $22 \quad[61]$ & $37 \quad[184]$ & $50 \quad[113]$ & $69[50]$ \\
\hline
\end{tabular}

